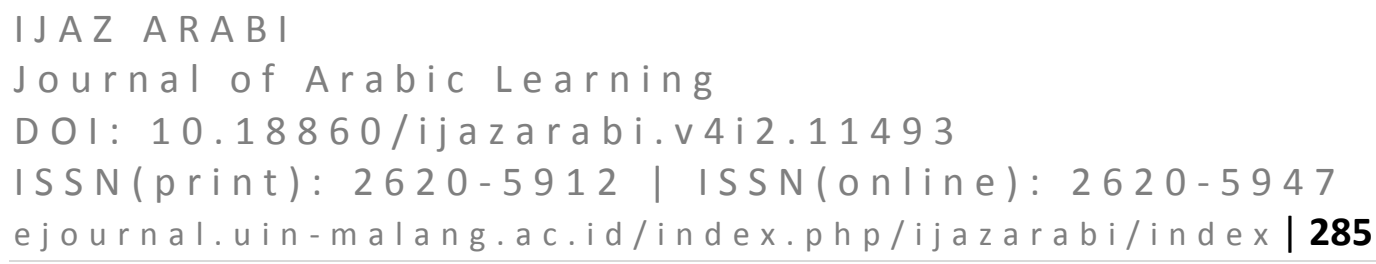

\title{
Employing Technological Pedagogical Content Knowledge (TPACK) Skill Among Teachers in Preparing Online School Assessment for Home-Based Learning
}

\author{
Muhammad Sabri Sahrir ${ }^{1}$, Abdul Razif Zaini ${ }^{2}$, Yaakob Hassan ${ }^{3}$, \\ Zulkefli Hamat ${ }^{4}$, Taufik Ismail ${ }^{5}$ \\ International Islamic University Malaysia (IIUM) ${ }^{\mathbf{1}}$, ICESCO Centre of \\ Education, Malaysia $^{2,3}$, Ministry of Education (MOE), Malaysia 4 \\ Selangor International Islamic College (KUIS) \\ muhdsabri@iium.edu.my ${ }^{1}$, abdulrazif@kuis.edu.my ${ }^{2}$, yaakob@kuis.edu.my ${ }^{3}$, \\ zulkefli.hamat@moe.gov.my ${ }^{4}$,taufik@iium.edu.my ${ }^{5}$
}

\begin{abstract}
The Technological Pedagogical Content Knowledge (TPACK) framework is crucial for every educators and teachers when dealing with teaching and learning by using technology. There are three essential components of TPACK which have to be fully mastered in order to conduct any teaching and learning session via whatever technological means and platforms, especially in the current situation of COVID-19 pandemic which requires the teacher to adapt with suitable teaching and learning remote strategies including online assessment. This study is conducted to investigate the level of technological pedagogical content knowledge (TPACK) skill among Arabic school teachers in preparing online assessment for remote teaching and learning prior to a training workshop organized by the Malaysian branch of Islamic World Educational, Scientific and Cultural Organization, ICESCO-KUIS and Islamic Education Unit, Ministry of Education, Malaysia. The main author has been conducting the TPACK training module among 56 Arabic school teachers in Johor, Malaysia on 5-6 October, 2020 from selected all districts, while only 40 of them responded to the survey after the workshop via Google Form. Moreover, all participants were responding concurrently to the open-ended survey during the workshop via Mentimeter.com. This research instruments were investigating the teachers' knowledge about three essential components of TPACK, which include technology, content, and pedagogy as well their suggestions and feedbacks towards employing online assessment and effectiveness of conducted workshop. The findings are expected in contributing towards the understanding of the teacher's level of knowledge in technology, pedagogy, and content among Arabic school teachers in Malaysia especially for online teaching and assessment. The study may also beneficial to other similar settings where the technology has not been effectively utilized by teachers in schools.
\end{abstract}

Keywords: TPACK; Technology; Remote Teaching And Learning; Online Assessment; Arabic Education. 


\section{INTRODUCTION}

The framework of Technological Pedagogical Content Knowledge (TPACK) is crucial for every researcher, educator and teacher when dealing with teaching and learning by using technology. Technological Pedagogical Content Knowledge (TPACK) was introduced by Mishra and Koehler (2006) as a generic framework for teacher knowledge in technology integration for teaching and learning known as TPCK. The framework was then rebranded into TPACK to make it easier to be remembered with a more clear integrated three elements of technology, pedagogy, and content (Thompson \& Mishra, 2007-2008).

Initially, TPACK is built on Shulman's (1986) study of PCK, with the addition of technological knowledge by Mishra and Koehler (2006), to explain effective teaching with the use of technology. Although, TPACK was mentioned by Mishra and Koehler (2006), this idea is not new, as several researchers have addressed a similar concept while describing the associations between technology, content, and pedagogy. The term TPCK referring to technology-enhanced PCK has been utilised by Niess (2005). There are three essential components of TPACK which have to be fully mastered in order to conduct any teaching and learning session via various technological means and platforms, especially in the current situation of COVID-19 pandemic which requires the teacher to adapt with suitable teaching and learning remote strategies including online assessment. For instance, the use of digital social media also can used during the global pandemic COVID19 (Mufidah \& Mohammad Idrees, 2020) by integrating all learning activities from home in various collaborating social media platforms as conducted by Leon, Trian, Ellen and Yogi (2021).

The use of technology in teaching and learning has becoming a crucial skill among teachers and educator especially in the $21^{\text {st }}$ century education. Moreover, the current global emergence situation of COVID-19 pandemic has been pushing the educators towards emergency remote teaching and learning (ERTL) and homebased learning (HBL) by using various online platforms and technologies (Leon, Trian, Ellen and Yogi, 2021). However, it is essential for the educators to master the TPACK knowledge and skill in order to ensure the proper conduct of online teaching and assessment. The development of three overlapping components of learning including content, pedagogy and technology in TPACK conceptualizes the pedagogical approaches (Mishra \& Koehler, 2006). Based on Hodges, Moore, Lockee, Trust, and Bond (2020), ERTL is well-planned online learning experiences for the courses offered in response to a crisis or disaster. In addition, the learners are pushed to opt in for the online learning option in some circumstances such as being in a war (Rajab, 2018), living in remote places (Chen \& Koricich, 2014), 2018), being a worker, and do not have time to attend regular classrooms (Bourne, et. al., 2005) as well as biological crisis (Alshehri. et. al., 2020). In the other hand, home-based learning (HBL) is an unavoidable option during the current spread of COVID-19 global pandemic. Based on Holt (2020) - who is the Father of HBL - 
home-based learning doesn't need to be like school; instead, it can be a continuation of how your family lived before your children became "school age".

Although there is positive impact of Information and Communications Technology (ICT) on various learning processes as reported by Romeo (2006), Cox and Graham (2009) have argued that TPACK is important to help educators in understanding the potential contributions of new technologies in education. According to Graham (2011), TPACK can be used to assess the way in which teachers' professional development affects their performance in the classroom with the use of ICT. The added value of TPACK can be found in the support it provides students through technology in their learning, and their development of conceptual, and procedural attributes (Voogt, Fisser, Pareja Roblin, Tondeur \& Van Braak, 2013).

In TPACK, the development of three overlapping components of learning including content, pedagogy and technology conceptualises the pedagogical approaches. It is commonly used for understanding, learning, and describing different knowledge types needed by educators and teachers (Mishra \& Koehler, 2006). Hence, it is supporting the argument by Bransford, Brown and Cocking (2000) that general teaching skills are required in order to revise with the use of advanced technologies for effective teaching. At the same time, Lee (2002) suggested that with the integration of ICT into schools, teachers ought to play the role of mentors, rather than expert in formation givers. Moreover, technological advancements in education should not only be focused, but additionally, there is the need for more effective learning tools (Romeo, 2006). Proper guidance also should be provided by the decision and policy makers while formulating the education policy in order to develop and implement technologies in teaching and learning (Lee, 2002).

On $31^{\text {st }}$ of December 2019, there was a growing report on the acute respiratory illness that started in China, specifically in the area of Wuhan City, Hubei Province, China. The virus, which is later identified as COVID-19, attacks the respiratory system and caused death to several thousands of individuals worldwide (Hasan \& Hossain, 2020; Chen, et. al., 2020; Ali, et. al., 2020). Hence, a majority of countries have announced the temporary closure of schools, impacting more than 91 per cent of students worldwide around 1.6 billion children and young people (Miks. J. and McIlwaine, J., 2020). Due to the seriousness of the rapid spread of this disease and to further prevent the spread, almost 1 billion people across the globe are put on home confinement (lockdown/movement control order) (NST Online, 22, March 2020) and Malaysia is of no exception. Rapid transmission of COVID-19 from human to human occurs through droplets or direct contact (Lai, Shih, Ko, Tang, \& Hsueh, 2020), which spreads when someone who is infected with COVID-19 coughs, sneezes or exhales (Williams, 2020).

The Prime Minister of Malaysia announced the first phase of the Movement Control Order (MCO) to start from 18th March until now in 2021. As such, all sectors including the education sector especially the Higher Education Institutions 


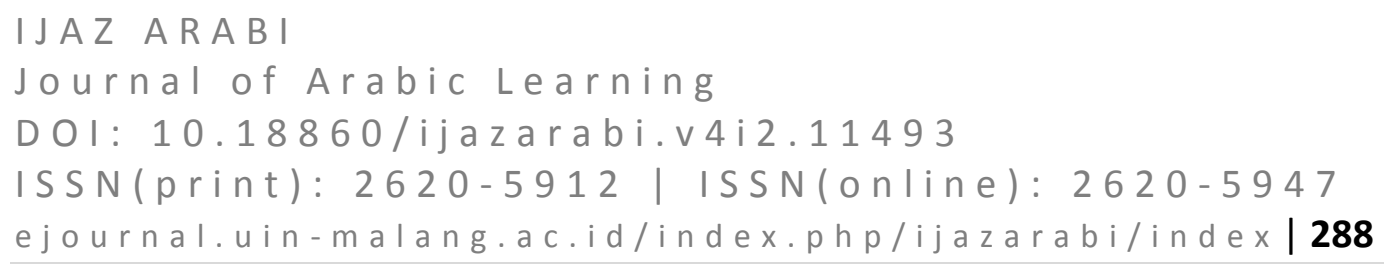

including schools are badly affected. Since the partial lockdown or MCO is unprecedented, teachers have been urged to explore the best teaching or instructional methods or strategies in teaching their students remotely. Hence, the teachers, support staff are busy trying and adapting with online learning activities with the hope of providing a support system for parents and a semblance of routine for the school students. This prompted, the Ministry of Education (MOE) to issue a circular on Teaching and Learning Implementation Guidelines (PdP) during the Movement Control Order (MCO) due COVID-19 pandemic.

The circular on Teaching and Learning Implementation Guidelines (PdP) consists of KPM's commitment to ensure that students are not left behind and are able to continue their learning in a safe manner. For this purpose, teachers are not allowed into the school and must perform all homework assignments from their homes (MOE, 2020-a). The Ministry of Education Malaysia has also issued a general manual or guideline for teachers to conduct teaching and learning activities at home, but so much in details on how to implement certain teaching and learning activities including the assessment (MOE, 2020-b). In Malaysia, computers have been making their way into schools since the late 1990s through Smart Schools programme. Until now, e-learning has been a feature in education since 2006 (Tunku Badariah, 2020). The Malaysian national e-learning policy (DePAN 2.0) was then officially announced on April 16, 2011 to open the path towards e-learning and online teaching more clearly nine years ago (MOHE, 2011). As such, this study is conducted to investigate the level of TPACK skill among Arabic language school teacher in Johor due to the current situation of COVID-19 pandemic which requires the teacher to adapt with suitable teaching and learning remote strategies including online assessment.

This study embarks on the following research questions: what is the level of Arabic school teachers' knowledge of technology, pedagogy, and content, including the combinations of these domains after undergone into the TPACK training in designing teaching and online assessment? What are comments and suggestions to empower the use of educational technology in Arabic teaching? What are comments and suggestions to empower the use of educational technology in Arabic assessment?

\section{METHOD}

As mentioned before, this study is conducted to investigate the level of technological pedagogical content knowledge (TPACK) skill among Arabic school teachers in preparing online assessment for remote teaching and learning. The respondents were purposively selected among 56 Arabic school teachers in Johor, Malaysia on 5-6 October, 2020 from selected all districts, while only 40 of them responded to the survey after the workshop via Google Form. Moreover, all participants were responding concurrently to the open-ended survey during the workshop via Mentimeter.com. This research instruments were investigating the teachers' knowledge about three essential components of TPACK, which include 


\section{IJAZ ARABI}

Journal of Arabic Learning

DOI: $10.18860 / \mathrm{ijazarabi.v4i2.11493}$

ISSN(print): $2620-5912$ | ISSN(online): $2620-5947$

ejournal.uin-malang.ac.id/index.php/ijazarabi/index

technology, content, and pedagogy as well their suggestions and feedbacks towards employing online assessment and effectiveness of conducted workshop organized by the Malaysian branch of Islamic World Educational, Scientific and Cultural Organization, ICESCO-KUIS and Islamic Education Unit, Ministry of Education, Malaysia. The respondents were allowed to complete the adapted TPACK survey by (Mishra \& Koehler, 2006; Shulman, 1986) in their own chosen place at a time that was convenient to them, via self-administered survey (Robson, 2002).

The first part of the survey is concerned with the collection of demographic information such as participants' gender, highest academic qualifications, school location and years of teaching experience. This aspect is useful to understand the background of all the respondents that facilitated in testing different variables. The second part of questionnaire is based on adapted TPACK as a guiding framework that enhanced the level of knowledge among the teachers in designing online assessment in 10 questions and 4 open-ended surveys (Mishra \& Koehler, 2006; Shulman, 1986; Archambault \& Barnett, 2010; Roberts, 1999; Schmidt, 2009).

\section{RESULTS AND FINDINGS}

The results for the results and findings are presented in separate subsections such as the followings:

\section{Demographic Information}

As shown in Table 1, it is very clear that most of the respondents are male with 22 respondents $(55) \%$, while the rests are female (45)\%.

Table 1: Gender

\begin{tabular}{c|c|c}
\hline Gender & Frequency $(\mathbf{N})$ & Percentage $(\%)$ \\
\hline Male & 22 & 55 \\
Female & 18 & 45 \\
\hline Total & $\mathbf{4 0}$ & $\mathbf{1 0 0}$
\end{tabular}

According to Table 2, the majority of respondents are above 31 years old (52.5\%), while the second largest of them are between the age of 31-35 (37.5\%) and 4 only teachers are in the range age of 26 to 30 .

Table 2: Age of Respondents

\begin{tabular}{c|c|c}
\hline Category of Age & Frequency $(\mathbf{N})$ & Percentage (\%) \\
\hline Below 25 & 0 & 0 \\
Between 26 and 30 & 4 & 10 \\
Between 31 and 35 & 15 & 37.5 \\
36 and above & 21 & 52.5 \\
\hline Total & $\mathbf{4 0}$ & $\mathbf{1 0 0}$
\end{tabular}

In terms of the highest academic qualification as reported in Table 3, most of the respondents hold the Bachelor degrees with $92.5 \%$, while small numbers of them have Diploma (5\%) and Master degrees (7.5\%). In addition to that, the respondents have different ranges of teaching experience at school from less than 5 years $(7.5 \%)$, between 5 and 10 years $(57.5 \%)$ and between 11 and 20 years (35\%) as displayed in Table 4. 
Journal of Arabic Learning

DOI: $10.18860 / \mathrm{ijazarabi.v4i2.11493}$

ISSN(print): $2620-5912$ | ISSN(onIine): $2620-5947$

ejournal.uin-malang.ac.id/index.php/ijazarabi/index/290

Table 3: Highest Academic Qualification

\begin{tabular}{c|c|c}
\hline Category of Age & Frequency $(\mathbf{N})$ & Percentage $(\%)$ \\
\hline Diploma & 2 & 5 \\
Bachelor & 37 & 92.5 \\
Master & 3 & 7.5 \\
PhD & 0 & 0 \\
\hline Total & $\mathbf{4 0}$ & $\mathbf{1 0 0}$ \\
\hline
\end{tabular}

Table 4: Teaching Experience at Schools

\begin{tabular}{c|c|c}
\hline Number of Years & Frequency $(\mathbf{N})$ & Percentage $(\%)$ \\
\hline Less than 5 years & 3 & 7.5 \\
Between 5 and 10 years & 23 & 57.5 \\
Between 11 and 20 years & 14 & 35 \\
More than 20 years & 0 & 0 \\
\hline Total & $\mathbf{4 0}$ & $\mathbf{1 0 0}$
\end{tabular}

The selected participants were coming from all over district of state of Johor in Malaysia, which indicates a big picture of findings from one of big states in Malaysia. Based on Table 5, the numbers are equally the same, with the biggest numbers were coming from Batu Pahat (17.5\%) and 12.5\% from Johor Bahru, Segamat and Pontian.

Table 5: Location of Schools based on Districts

\begin{tabular}{c|c|c}
\hline Districts & Frequency $(\mathbf{N})$ & Percentage (\%) \\
\hline Johor Bahru & 5 & 12.5 \\
Muar & 4 & 10 \\
Batu Pahat & 7 & 17.5 \\
Segamat & 5 & 12.5 \\
Kluang & 1 & 2.5 \\
Pontian & 5 & 12.5 \\
Kota Tinggi & 3 & 7.5 \\
Mersing & 1 & 2.5 \\
Kulai & 4 & 10 \\
Tangkak & 3 & 7.5 \\
Lain-lain & 2 & 5 \\
\hline Total & $\mathbf{4 0}$ & $\mathbf{1 0 0}$
\end{tabular}

\section{Competency Level On Technological Pedagogical Content Knowledge (TPACK)}

The results competency level on technological pedagogical content knowledge (TPACK) among Arabic school teachers are displayed in Table 6 as the following: 
Table 6: Results of TPACK Survey

\begin{tabular}{|c|c|c|c|c|c|c|}
\hline $\mathrm{N}$ & \multirow[t]{2}{*}{ Item } & \multicolumn{5}{|c|}{ Frequency and Percentage } \\
\hline o. & & SD & $\mathrm{D}$ & $\mathrm{N}$ & $\mathrm{A}$ & SA \\
\hline 1 & $\begin{array}{l}\text { I can search for materials with } \\
\text { the help of educational } \\
\text { technology to understand } \\
\text { Arabic and use them in the } \\
\text { teaching process. }\end{array}$ & 0 & 0 & 0 & $\begin{array}{c}20 \\
(50 \%)\end{array}$ & $\begin{array}{c}20 \\
(50 \%)\end{array}$ \\
\hline 2 & $\begin{array}{l}\text { I can use the internet to } \\
\text { understand Arabic and use it } \\
\text { in the } T \& L \text { process. }\end{array}$ & 0 & 0 & 0 & $\begin{array}{c}22 \\
(55 \%)\end{array}$ & $\begin{array}{c}18 \\
(45 \%)\end{array}$ \\
\hline 3 & $\begin{array}{l}\text { I can use a teaching strategy } \\
\text { that combines Arabic content, } \\
\text { educational technology and } \\
\text { pedagogy. }\end{array}$ & 0 & 0 & 0 & $\begin{array}{c}23 \\
(57.5 \%)\end{array}$ & $\begin{array}{c}17 \\
(42.5 \%)\end{array}$ \\
\hline 4 & $\begin{array}{l}\text { I can choose Arabic resources } \\
\text { and educational technology } \\
\text { innovations based on } \\
\text { suitability to meet the needs of } \\
\text { the Arabic T\&L. }\end{array}$ & 0 & 0 & $\begin{array}{c}2 \\
(5 \%)\end{array}$ & $\begin{array}{c}25 \\
(62.5 \%)\end{array}$ & $\begin{array}{c}13 \\
(32.5 \%)\end{array}$ \\
\hline 5 & $\begin{array}{l}\text { I can teach Arabic by } \\
\text { combining pedagogy, Arabic } \\
\text { content and educational } \\
\text { technology. }\end{array}$ & 0 & 0 & 0 & $\begin{array}{c}25 \\
(62.5 \%)\end{array}$ & $\begin{array}{c}15 \\
(37.5 \%)\end{array}$ \\
\hline 6 & $\begin{array}{l}\text { I can assess Arabic resources } \\
\text { and educational technology } \\
\text { innovations to meet the needs } \\
\text { of the Arabic T\&L. }\end{array}$ & 0 & 0 & $\begin{array}{c}2 \\
(5 \%)\end{array}$ & $\begin{array}{c}26 \\
(65 \%)\end{array}$ & $\begin{array}{c}12 \\
(30 \%)\end{array}$ \\
\hline 7 & $\begin{array}{l}\text { I can use educational } \\
\text { technology to understand } \\
\text { Arabic to support the Arabic } \\
\text { T\&L. }\end{array}$ & 0 & 0 & $\begin{array}{c}1 \\
(2.5 \%)\end{array}$ & $\begin{array}{c}25 \\
(62.5 \%)\end{array}$ & $\begin{array}{c}14 \\
(35 \%)\end{array}$ \\
\hline 8 & $\begin{array}{l}\text { I can use educational } \\
\text { technology to understand } \\
\text { Arabic to support Arabic } \\
\text { research. }\end{array}$ & 0 & 0 & $\begin{array}{c}1 \\
(2.5 \%)\end{array}$ & $\begin{array}{c}27 \\
(67.5 \%)\end{array}$ & $\begin{array}{c}12 \\
(30 \%)\end{array}$ \\
\hline 9 & $\begin{array}{l}\text { I can demonstrate leadership } \\
\text { in helping others coordinate } \\
\text { the use of Arabic content, } \\
\text { educational technology and } \\
\text { pedagogy in schools. }\end{array}$ & 0 & $\begin{array}{c}1 \\
(2.5 \\
\%)\end{array}$ & $\begin{array}{c}5 \\
(12.5 \\
\%)\end{array}$ & $\begin{array}{c}22 \\
(55 \%)\end{array}$ & $\begin{array}{c}12 \\
(30 \%)\end{array}$ \\
\hline $\begin{array}{l}1 \\
0\end{array}$ & $\begin{array}{l}\text { I can find materials with the } \\
\text { help of educational }\end{array}$ & 0 & 0 & 0 & $\begin{array}{c}25 \\
(62.5 \%)\end{array}$ & $\begin{array}{c}15 \\
(37.5 \%)\end{array}$ \\
\hline
\end{tabular}




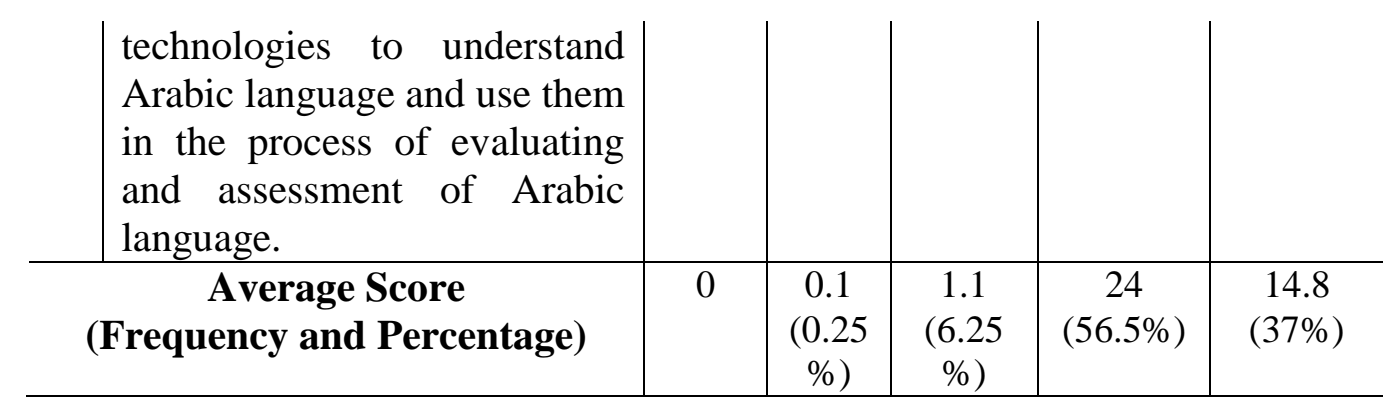

Based on Table 6 , the average frequency and percentage results and findings are showing a clear high level TPACK competency level among respondents. After participating in the workshop, the Arabic language teacher are having high confidence of TPACK skill in searching and using Arabic resources and educational technology to meet the needs of the Arabic teaching and learning (item 1.2.3, 5 and 10). However, few of them are still not sure and weak in selecting and assessing Arabic resources and educational technology to facilitate the needs of the Arabic teaching, learning and research (item 4.6.7, 8 and 9).

Moreover, item 10 indicates that the majority of respondents can find materials with the help of educational technologies to understand Arabic language and use them in the process of evaluating and assessment of Arabic language with $62.5 \%$ in Agree and $37.5 \%$ in Strongly Agree which show their readiness towards implementing online assessments in the schools. The weakest element recorded in TPACK skill is related to demonstrating leadership in helping others coordinate the use of Arabic content, educational technology and pedagogy in schools (item 9) which may indicate the particular teacher may not reach the competency level that enable him or her to be the trainer or mentor for other peer school teachers.

\section{Further Comments And Suggestions To Empower The Use Of Educational Technology In Arabic Teaching}

Almost 33 responses were gathered for this question which can be summarized as shown below:

Table 7: Further comments and suggestions in light of the use of educational technology in Arabic teaching

\begin{tabular}{|c|c|c|}
\hline No. & Main Theme & Sub Theme \\
\hline 1 & $\begin{array}{l}\text { Technological } \\
\text { support }\end{array}$ & $\begin{array}{l}\text { - Easier access to Arabic language multimedia } \\
\text { programs. } \\
\text { - Empower the use of technology to all Arabic } \\
\text { language teachers in Malaysia. } \\
\text { - Preparation of technological materials. } \\
\text { - Hold more seminars or courses on the importance } \\
\text { of technology for all Arabic language teachers. } \\
\text { - Providing cheaper and faster data. }\end{array}$ \\
\hline
\end{tabular}




\begin{tabular}{|c|c|c|}
\hline & & $\begin{array}{l}\text { - Supplying teaching aids based technology } \\
\text { specifically for teaching Arabic such as electronic } \\
\text { devices and so on. } \\
\text { - Empower internet access in schools so that all } \\
\text { students can use it. }\end{array}$ \\
\hline 2 & $\begin{array}{l}\text { E-Learning } \\
\text { resources }\end{array}$ & $\begin{array}{l}\text { - Increasing the Arabic language multimedia } \\
\text { programs. } \\
\text { - More Arabic language technology terms are coined. } \\
\text { - Improving educational technology resources in } \\
\text { schools. } \\
\text { - Distribute applications that can be used for Arabic } \\
\text { teaching and learning. }\end{array}$ \\
\hline 3 & $\begin{array}{l}\text { Instructional } \\
\text { support }\end{array}$ & $\begin{array}{l}\text { - Techniques of constructing interactive sheet } \\
\text { questions. } \\
\text { - Conducting teaching and learning.courses for all } \\
\text { Arabic language teachers. } \\
\text { - More detailed disclosure on the use of PAK } 21 \\
\text { applications. } \\
\text { - Organize special programs and approaches for all } \\
\text { Arabic language teachers. } \\
\text { - Organizing special competitions. }\end{array}$ \\
\hline
\end{tabular}

From the open-ended responses, the findings in general can be divided into 3 main themes of technological support, e-learning resources and instructional support for both of comments and suggestions in light of the use of educational technology in Arabic teaching and learning.

\section{Further Proposals To Empower The Use Of Educational Technology In} Arabic Assessment

Almost 28 responses were gathered for this question which can be summarized as shown below:

Table 8: Further comments and suggestions in light of the use of educational technology in Arabic assessment

\begin{tabular}{|c|c|c|}
\hline No & Main Theme & Sub Theme \\
\hline 1 & $\begin{array}{l}\text { Technological } \\
\text { support }\end{array}$ & $\begin{array}{l}\text { Enhance the internet facilities. } \\
\text { Creating applications that are beneficial to all } \\
\text { teachers and students learning Arabic. } \\
\text { Need to expand the internet in schools, especially } \\
\text { in the classroom such as LCD technical support. } \\
\text { Increase the use of ICT in teaching and learning. } \\
\text { Providing computers and internet access. } \\
\text { Providing faster internet access. }\end{array}$ \\
\hline
\end{tabular}




\begin{tabular}{l|l|l}
\hline & & $\begin{array}{l}\text { Empower internet access in schools so that all } \\
\text { students can use it. } \\
\text { Provision of high-speed internet speed. }\end{array}$ \\
\hline 3 & $\begin{array}{l}\text { E-Learning } \\
\text { resources }\end{array}$ & $\begin{array}{l}\text { Increasing the use of Arabic words for each } \\
\text { application. } \\
\text { Free website resources are introduced and taught to } \\
\text { teachers. } \\
\text { Disclosure the assessment method in using } \\
\text { technology more easily and effectively. }\end{array}$ \\
\hline $\begin{array}{l}\text { Encouraging Arabic language teachers to use } \\
\text { educational technology in assessment. } \\
\text { Empowering teachers in the use of technology. } \\
\text { Conducting in-house training at school and district } \\
\text { levels. } \\
\text { Introducing devices that facilitate the use of } \\
\text { technology in teaching and learning. } \\
\text { Conducting teaching and learning courses for all } \\
\text { Arabic language teachers. } \\
\text { Adapting more learning modules to student } \\
\text { activities in the 21st century. } \\
\text { Strengthen teachers teaching in the use of } \\
\text { technology. } \\
\text { Organizing competitions and providing awards. }\end{array}$ \\
\hline
\end{tabular}

From the open-ended responses, the findings in general can be divided into 3 main themes of technological support, e-learning resources and instructional support for both of comments and suggestions in light of the use of educational technology in preparing Arabic assessments.

\section{The Effectiveness Of TPACK Workshop In Enhancing The Tpack Skill Among Arabic School Teachers}

In the one of the final sessions in the 2-day workshop, the participants were asked to participate in an open-ended survey on effectiveness of this TPACK workshop via Mentimeter.com. The word cloud response in Figure 1 show that they are mostly satisfied with various positive feedbacks.

Figure 1: Perceived effectiveness of TPACK workshop by participants

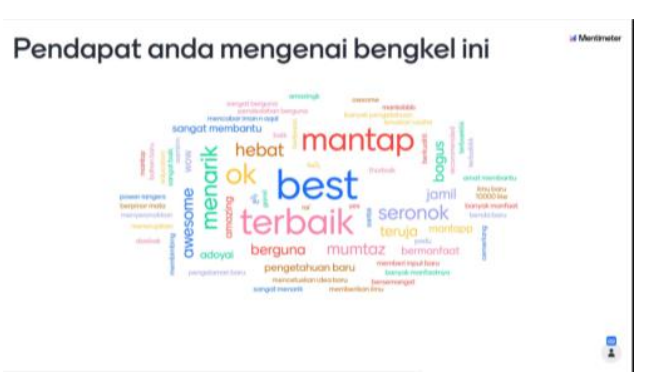




\section{DISCUSSIONS}

In general, this study show that the Arabic language teacher are having high confidence of TPACK skill when they are dealing with teaching and learning Arabic language at schools. However, few elements are still in need to be improved based on the results and findings which are related to higher technological element of TPACK.

The ministry of education may need to empower the aspect of selecting and assessing Arabic resources and educational technology to facilitate the needs of the Arabic teaching, learning and research, in addition to demonstrating leadership in helping others to use Arabic content, educational technology and pedagogy in schools which may indicate the uncapable competency that enable the teacher to be the trainer or mentor for other peer school teachers. This teaching mentorship is practiced in the schools known as "Jurulatih Utama" or Main Trainer.

From the open-ended responses, the findings in general can be divided into 3 main themes of technological support, e-learning resources and instructional support for both of comments and suggestions in light of the use of educational technology in Arabic teaching and assessment. The comments and suggestions can be collaboratively addressed by various levels of authorities and personnel such as teachers, expert teachers, schools, school administration divisions at the district, state and national levels. Better coordination between these parties may be more useful and fruitful in order to maximize the effective implementation of TPACK skill and teaching and assessment.

\section{CONCLUSION}

This study was conducted to investigate the level of technological pedagogical content knowledge (TPACK) skill among Arabic school teachers in preparing online assessment for remote teaching and learning prior to a training workshop. In light of the findings, it is implicit that this study has revealed few pertinent issues that needs to be improved and enhanced in terms of the implementation of TPACK skill and teaching and assessment especially among Arabic language school teachers in Johor, Malaysia. However, this workshop is found to be positively evaluated by the participants in improving their TPACK skill.

\section{ACKNOWLEDGEMENT}

The authors would like to thank the Kulliyyah of Education International Islamic University Malaysia (IIUM) for funding this research project under IIUM Hassan Langulung Grant 2020.

\section{REFERENCES}

Ali, M. G., Ahmad, M. O., \& Husain, S. N. (2020). Spread of Corona Virus Disease (Covid-19) from an Outbreak to Pandemic in the Year 2020. Asian Journal of Research in Infectious Diseases, 3, 37-51. 
Journal of Arabic Learning

DOI: $10.18860 / \mathrm{ijazarabi.v4i2.11493}$

ISSN(print): $2620-5912$ | ISSN(onIine): 2620-5947

ejournal.uin-malang.ac.id/index.php/ijazarabi/index/296

Alshehri, Y. , Mordhah, N. , Alsibiani, S. , Alsobhi, S. and Alnazzawi, N. (2020) How the Regular Teaching Converted to Fully Online Teaching in Saudi Arabia during the Coronavirus COVID-19. Creative Education, 11, 985996. doi: 10.4236/ce.2020.117071.

Archambault LM \& Barnett JH (2010). Revisiting technological pedagogical content knowledge: Exploring the TPACK framework. Computers and Education, 55(4):1656-1662.

Bourne, J., Harris, D., \& Mayadas, F. (2005). Online Engineering Education: Learning Anywhere, Anytime. Journal of Engineering Education, 94, 131 146.

Bransford JD, Brown AL \& Cocking RR (2000). How people learn: Brain, mind, experience, and school (eds). Washington, DC: National Academy Press.

Chen, X., \& Koricich, A. (2014). Reaching Out to Remote Places: A Discussion of

Technology and the Future of Distance Education in Rural America. In E-Learn: World Conference on eLearning in Corporate, Government, Healthcare, and Higher Education (pp. 370-376). San Diego, CA: Association for the Advancement of Computing in Education (AACE).

Chen, Q., Quan, B., Li, X., Gao, G., Zheng, W., Zhang, J., Zhang, Z., Liu, C., Li, L., Wang, C. et al. (2020). A Report of Clinical Diagnosis and Treatment of 9 Cases of Coronavirus Disease 2019. Journal of Medical Virology, 92, 683687. https://doi.org/10.1002/jmv.25755

Cox S \& Graham CR (2009). Diagramming TPACK in practice: Using an elaborated model of The TPACK framework to analyze and depict teacher knowledge. TechTrends, 53(5):60-69.

Cronbach LJ (1951). Coefficient alpha and the internal structure of tests. Psychometrika, 16(3):297-334.

Graham CR (2011). Theoretical considerations for understanding technological pedagogical content knowledge (TPACK). Computers and Education, 57(3):1953-1960.

Hasan, S., \& Hossain, M. M. (2020). Analysis of Covid-19 m Protein for Possible Clues Regarding Virion Stability, Longevity and Spreading. https://doi.org/10.31219/osf.io/e7jkc

Hodges, C., Moore, S., Lockee, B., Trust, T., \& Bond, A. (2020). The Difference between Emergency Remote Teaching and Online Learning. EDUCAUSE Review.

Holt, J. (2020). Home-Based Learning, Alternatives to Schools. Link: alternativestoschool.com/articles/home-based-learning/

Lai, C. C., Shih, T. P., Ko, W. C., Tang, H. J., \& Hsueh, P. R. (2020). Severe acute respiratory syndrome coronavirus 2 (SARS-CoV-2) and coronavirus disease 2019 (COVID-19): The epidemic and the challenges. International Journal of Antimicrobial Agents, 55(3), 105924. https://doi.org/10.1016/j.ijantimicag.2020.105924 
IJAZ ARABI

Journal of Arabic Learning

DOI: $10.18860 / \mathrm{ijazarabi.v4i2.11493}$

ISSN(print): $2620-5912$ | ISSN(online): $2620-5947$

ejournal.uin-malang.ac.id/index.php/ijazarabi/index/

Lee KT (2002). Effective teaching in the information era: Fostering an ICT- based integrated learning environment in schools. Asia-Pacific Journal for Teacher Education and Development, 5(1):21-45.

Leon Abdillah, Trian Handayani, Ellen R Rosalyn, Yogi I Mukti (2021). Collaborating Digital Social Media for Teaching Science and Arabic in Higher Education During COVID-19 Pandemic. Ijaz Arabi Journal of Arabic Learning, 4(1), 12-25. https://doi.org/10.18860/ijazarabi.v4i1.10793

Miks. J. and McIlwaine, J. (2020). Keeping the world's children learning through COVID-19, UNICEF website. Link: https://www.unicef.org/coronavirus/keeping-worlds-I children- learning-through-covid-19

Mishra P \& Koehler MJ (2006). Technological pedagogical content knowledge: A framework for teacher knowledge. Teachers College Record, 108(6):10171054.

MOE (2020-a). Guidelines for Teaching and Learning Implementation (T\&L) During Movement Control Orders (MCO). Link: https://www.pendidik2u.my/garis-panduan-pelaksanaan- pdp-semasaperintah-kawalan-pergerakan/

MOE (2020-b). Manual Pengajaran dan Pembelajaran di Rumah. Ministry of Education Malaysia. Link: laporan Webinar Perkongsian Pengajaran dan Pembelajaran (PDP) Normal Baharu (moe.gov.my)

MOHE (2011). Dasar e-Pembelajaran Negara 2.0. Ministry of Higher Education Malaysia and MEIPTA. Link: PTPA1_DePAN_v2.pdf (upm.edu.my)

Mufidah, N., \& Mohammad Idrees, M. U. H. (2020). Self-Learning Strategy in Teaching Speech Skills to Face COVID 19/

COVID 19. Ijaz Arabi Journal of Arabic Learning, 33-45. https://doi.org/10.18860/ijazarabi.v3i1.10154

Niess ML (2005). Preparing Teachers To Teach Science And Mathematics With Technology: Developing A Technology Pedagogical Content Knowledge. Teaching and Teacher Education, 21(5):509-523.

NST Online (2020). Covid-19: Nearly One Billion Under Lockdown Worldwide. $22^{\text {nd }}$ of March.

Rajab, K. D. (2018). The Effectiveness and Potential of e-Learning in War Zones: An Empirical Comparison of Face-to-Face and Online Education in Saudi Arabia. IEEE Access, 6, 6783-6794. https://doi.org/10.1109/ACCESS.2018.2800164

Roberts ES (1999). In Defence Of The Survey Method: An Illustration From A Study Of User Information Satisfaction. Accounting and Finance, 39(1):5377.

Robson C (2002). Real World Research: A Resource For Social Scientists And Practitioner-Researchers (2nd ed). Oxford, England: Blackwell. 
Romeo G (2006). Engage, Empower, Enable: Developing A Shared Vision For Technology In Education. In D Hung \& MS Khine (eds). Engaged Learning With Emerging Technologies. Dordrecht, The Netherlands: Springer.

Schmidt M (2009). Special issue: Societal aspects of synthetic biology. Systems And Synthetic Biology, 3:1.

Shulman LS (1986). Those who understand: Knowledge Growth In Teaching. Educational Researcher, 15(2):4-14.

Thompson, A., \& Mishra, P. (2007-2008). Breaking news: TPCK Becomes TPACK! Journal of Computing in Teacher Education, 24(2), 38-64.

Tunku Badariah, T.A., (2020). Teaching Remotely During COVID-19: Opportunities For Creativity And Innovation. IIUM Journal of Educational Studies, 8:1(2020) pp. 1-3.

Voogt J, Fisser P, Pareja Roblin N, Tondeur J \& Van Braak J (2013). Technological pedagogical content knowledge - a review of the literature. Journal of Computer Assisted Learning, 29(2):109-121.

Voogt J \& Roblin NP (2012). A Comparative Analysis Of International Frameworks For 21st Century Competences: Implications For National Curriculum Policies. Journal of Curriculum Studies, 44(3):299-321.

Williams, T. (2020). Breaking The Chain Of Infection. Journal of Perioperative Practice, 30(4), 83-84. https://doi.org/10.1177/1750458920914256 